\title{
PENANGANAN NARAPIDANA RISIKO TINGGI DALAM PEMENUHAN HAK-HAKNYA UNTUK MENDAPATKAN PROGRAM PEMBEBASAN BERSYARAT DI LAPAS KELAS I MAKASSAR
}

\section{Handling Of High Risk Prisoners in Fulfilling Their Rights to be Eligible for Parole Programs in Class I Penitentiary Makassar}

\author{
Rosliani ${ }^{1}$, Marwan Mas $^{2}$, Abdul Salam Siku ${ }^{2}$ \\ ${ }^{1}$ Lembaga Permasyarakatan Kelas I Makassar \\ ${ }^{2}$ Program Studi Ilmu Hukum Program Pascasarjana Universitas Bosowa \\ Email: roslianiwahid@gmail.com
}

Diterima: 12 Agustus 2020/Disetujui: 07 Desember 2020

\begin{abstract}
ABSTRAK
Penelitian ini bertujuan untuk mengetahui pelaksanaan pemberian pembebasan bersyarat bagi narapidana di Lembaga Pemasyarakatan (LAPAS) Kelas I Makassar serta mengetahui bagaimana perlakuan khusus terhadap narapidana risiko tinggi di dalam lembaga pemasyarakatan serta implementasi kebijakan perlakuan khusus terhadap narapidana risiko tinggi di lembaga pemasyarakatan. Penelitian ini dilaksanakan di Kota Makassar pada Kantor Lembaga Pemasyarakatan Kelas I Kota Makassar. Metode yang digunakan penulis adalah pendekatan normative empiris. Maksudnya pendekatan yang dilakukan untuk menganalisa tentang sejauh manakah suatu peraturan atau perundang-undangan atau hukum yang sedang berlaku secara efektif dalam masyarakat mengenai pelaksanaan pemberian pembebasan bersyarat bagi narapidana di Lembaga Pemasyarakatan (LAPAS) Kelas I Makassar. Hasil penelitian ini menunjukkan bahwa penanganan narapidana resiko tinggi pada Lapas Kelas I Makassar sudah cukup efektif dengan menempatkan narapidana resiko tinggi ditempat terpisah dengan narapidana tindak pidana lain serta pemberian program pembebasan bersyarat agar narapidana memperoleh kesempatan beradaptasi dan berbaur kembali dengan masyarakat luas.
\end{abstract}

Kata Kunci: Lapas, Resiko Tinggi, Pembebasan Bersyarat

\begin{abstract}
This study aims to determine the implementation of parole for prisoners in Class I Penitentiary (LAPAS) Makassar and to find out how the special treatment of high-risk prisoners in penitentiary and the implementation of special treatment policies for high-risk prisoners in penitentiary. This research was conducted in Makassar in the Class I Penitentiary Office. The method used was an empirical normative approach. The purpose of this approach taken was to analyze the extent of a regulation or legislation or law applicable in the community regarding the implementation of granting parole for prisoners in Class I Penitentiary Makassar. The results of this study indicate that the handling of high-risk prisoners in Class I Penitentiary Makassar is quite effective by placing high-risk prisoners separated from other criminal inmates and providing parole programs so that prisoners have the opportunity to adapt and socialise with a wider community.
\end{abstract}

Keywords: Penitentiary, High Risk, Parole

\section{PENDAhuluan}

Indonesia merupakan negara yang saat ini termasuk dalam kategori negara yang sedang berkembang. Banyaknya persoalan yang telah dihadapi negara maju, mengharuskan Negara Indonesia membuat regulasi untuk mengatasi pesatnya arus globalisasi. Sebagai dampak yang akan berpengaruh terhadap populasi masyarakat Indonesia, maka masalah yang akan dihadapi bermula dari sektor ekonomi (kebutuhan manusia), persoalan minimnya lapangan pekerjaan yang berpengaruh terhadap bertumbuhnya angka kriminalitas maupun pelanggaran hak asasi manusia, bahkan berujung kepada masalah yang berhubungan dengan jaringan kejahatan internasional atau biasa disebut kejahatan antar Negara

Terkait masalah kriminal saat ini, telah banyak macam perbuatan Kriminal yang dihadapkan dipersidangan seperti penipuan, perjudian penganiayaan, pembunuhan, tindak pemerkosaan, pencurian, perampokan sebagaimana yang tertuang pada Kitab Undang - undang Hukum Pidana (KUHP), aksi terorisme, sindikat narkotika, perilaku korupsi, (tindak pidana khusus) bahkan tindak 
kejahatan informasi teknologi elektronik atau biasa disebut ITE yang peraturan hukumnya diluar KUHP.

Dari banyaknya rentetan kasus yang telah terjadi dan berbagai jenis pelanggaran hukum, membuat penegak hukum terus mencari terobosan baru agar menekan angka tindakan kriminal menurun serta meminimalisir potensi pengulangan tindak pidana. Berbagai upaya telah dilakukan demi mewujudkan penegakan hukum yang berbasis pada tumbuhnya kesadaran hukum bagi para Narapidana. Pasal 1 ayat 7 Undang - undang No. 12 Tahun 1995 Tentang Pemasyarakatan Menyebutkan bahwa Narapidana adalah Terpidana yang menjalani pidana hilang kemerdekaan di LAPAS.

Pidana penjara dalam sistem pemasyarakatan dilaksanakan dengan menjunjung tinggi nilai- nilai hak asasi manusia. Perlakuan seperti ini dimaksudkan untuk menjaga posisi narapidana untuk tidak dijadikan objek pembinaan, melainkan sebagai subjek pada proses pembinaan dengan tujuan akhir memulihkan status sosial narapidana untuk kembali ke tengah - tengah masyarakat sebagai orang yang bermanfaat, baik serta berguna bagi orang banyak (Suwarto, 2009).

Upaya proses pembinaan yang meliputi bimbingan dapat menjadi inti pada kegiatan sistem pemasyarakatan, perlakuan cara dan kelola program pembinaan dengan baik dapat membuat terpenuhinya hak-hak narapidana. Pembinaan terhadap narapidana dilaksanakan melalui tiga tahapan, diantaranya, yaitu tahap pertama, tahap lanjutan dan tahap akhir. Pembinaan tahap pertama bagi narapidana dimulai dari yang bersangkutan telah berstatus sebagai narapidana sampai dengan $1 / 3$ (sepertiga) dari masa pidana yang dijalani, selanjutnya Pembinaan tahap lanjutan terbagi atas 3 (tiga) yaitu:

1. Tahap lanjutan awal, setelah berakhirnya pembinaan tahap pertama sampai dengan $1 / 2$ (seperdua) dari masa pidana yang telah dijalani;

2. Tahap lanjutan berikutnya, setelah berakhirnya pembinaan tahap lanjutan awal sampai dengan $2 / 3$ (dua pertiga) dari masa pidana.

3. Pembinaan tahap akhir dilaksanakan setelah berakhirnya tahap kedua / lanjutan sampai dengan berakhirnya periode masa tahanan pidana dari narapidana tersebut.

Pengalihan tahapan pembinaan dilakukan melalui sidang oleh team pengamat pemasyarakatan dengan memperhatikan hasil penelitian kemasyarakatan (litmas). Dari hasil penelitian kemasyarakatan tersebut, maka dapat diklasifikasikan model pembinaan dan penempatan narapidana berdasarkan kebutuhan dan risikonya. Dengan demikian maka model perlakuan khusus kepada narapidana tertentu merupakan tujuan untuk mencapai efektifitas pelaksanaan pembinaan.

Kenyataannya tidak semua program penanganan dan pembinaan tersebut mampu menjawab kebutuhan dan permasalahan yang dialami narapidana, sehingga mengakibatkan terjadinya perilaku dari narapidana yang agresif dan melanggar aturan didalam Lapas.

Peningkatan jumlah penghuni Lapas/Rutan yang tidak selaras dengan penambahan kapasitas hunian, menyebabkan terjadinya penumpukan jumlah penghuni diLapas. Kondisi over crowded ini berpengaruh terhadap tidak optimalnya pembinaan dan kenyamanan di dalam lembaga sehingga menimbulkan narapidana berupaya untuk melakukan hal-hal yang bertentangan dengan aturan dalam lembaga pemasyarakatan. Tidak semua narapidana yang diusulkan dapat pula terealisasi semuanya, hal ini karena ulah si narapidana sendirilah yang menghambat proses pelaksanaan pemberian hak narapidana untuk mendapatkan pembebasan bersyarat (Immawati, at.al, 2020).

Adanya konotasi negatif tentang aktivitas pemasyarakatan seperti maraknya peredaran obat-obatan terlarang, pengendalian narkotika didalam lapas, komersialisasi kamar mewah, persekongkolan pelarian dan tentang kasus "plesiran" narapidana di Lapas Sukamiskin menunjukan adanya pelanggaran ketertiban dan peraturan lapas. Akibat "kasus plesiran" itu pelaku tersebut dialihkan ke Lembaga Pemasyarakatan Gn. Sindur karena telah dinilai sebagai narapidana yang berisiko tinggi. Keberadaan narapidana risiko tinggi dilapas konvensional dikhawatirkan bisa mengganggu sistem pembinaan pemasyarakatan, oleh karena itu Kemenkumham melalui Direktorat Jenderal Pemasyarakatan membangun sebuah Lapas yang berfungsi sebagai Lembaga pemasyarkatan Super Maximum Security (SMS). Sesuai dengan Pasal 8 ayat 2 dan Pasal 9, Peraturan Menteri Hukum \& Hak Asasi Manusia No. 35 Th. 2018 tentang Revitalisasi Penyelenggaraan Pemasyarakatan.

Dahulu, Lapas disebut Rumah Penjara, yakni tempat dimana orang-orang yang telah dijatuhi pidana dengan pidana tertentu oleh hakim itu harus menjalankan pidana mereka. Sesuai dengan gagasan Sahardjo yang pada waktu itu menjabat Menteri Kehakiman, sebutan penjara di Indonesia sejak April 1964 diubah menjadi Lembaga Pemasyarakatan (LAPAS). Perubahan nama penjara menjadi Lapas tidak dapat dilepaskan dari gagasan Sahardjo yang menjadikan Lapas tidak saja sebagai tempat memidana orang, melainkan juga sebagai tempat membina atau mendidik terpidana agar setelah selesai menjalankan pidana, mempunyai kemampuan untuk menyesuaikan diri dengan kehidupan diluar Lapas sebagai warga negara yang baik dan taat pada hukum yang berlaku (Lamintang, 2000)

Lapas ini diharapkan dapat menampung narapidana yang meresahkan sesama narapidana dan petugas, seperti bandar narkotika yang kasusnya berat, teroris yang menyebarkan ideologi, dan koruptor yang kasusnya besar. Narapidana risiko tinggi ini dianggap bisa mempengaruhi penghuni lainnya. Pasal 10 ayat (1) Peraturan Menteri Hukum \& Hak Asasi Manusia No. 35 th 2018 tentang Revitalisasi Penyelenggaraan Pemasyarakatan, narapidana berisiko tinggi atau narapidana high risk adalah narapidana yang membahayakan keamanan negara dan / atau membahayakan keselamatan masyarakat. Selain narapidana yang melanggar aturan di Lembaga Pemasyarakatan, Dirjen Pemasyarakatan mengkategorikan pelaku tindak pidana kejahatan sindikat narkotika psikotropika, aksiteroris, trafficking, illegal loging, illegal fishing atau korupsi sebagai Narapidana Risiko Tinggi.

Meskipun demikian pidana umum juga mempunyai potensi menjadi berisiko tinggi atau high risk apabila narapidana tersebut berperilaku agresif atau berpotensi mengganggu ketertiban umum didalam penjara. Oleh karena itu perlu dilakukan penilaian terhadap narapidana tersebut. 
Mantan Direktur Jenderal Pemasyarakatan

Kemenkumham memaparkan dalam wawancara kepada gresnews.com mengenai kategori masyarakat binaan baru yang biasa disebut sebagai narapidana dengan tingkat risiko tinggi atau high risk. Menurutnya, ada beberapa klasifikasi khususnya yang berkaitan dengan kejahatan luar biasa atau biasa disebut extraordinarycrime, seperti pada kasus korupsi yang secara langsung tidak ada yang dibahayakan tapi jelas sudah merugikan keuangan negara. Walaupun tidak ada yang dibahayakan tetap kasus korupsi dikategorikan sebagai risiko tinggi karena hukumannya yang tinggi dan ditempatkan ke dalam Lapas Maximum Security karena memiliki risiko untuk melarikan diri pada masa pemeriksaan atau risiko bunuh diri.

Berdasarkan ketentuan diatas, bahwa salah satu hak dari narapidana adalah memperoleh pembebasan bersyarat. Hak memperoleh pembebasan bersyarat berdasarkan kategori tingkatan resiko tinggi telah dilakukan penelitian terhadap warga binaan untuk mengukur kelayakan narapidana saat diajukan pemberian bebas bersyarat. Program ini dilaksanakan dengan pengamatan mendalam untuk menentukan tingkat resiko tinggi yang pantas dan tidak berdampak pada penilaian negatif terhadap narapidana lainnya.

Adapun tujuan dari penelitian ini adalah untuk mengetahui sistem pelaksanaan dan teknis pemberian pembebasan bersyarat terhadap narapidana di LAPAS Kelas I Makassar dan untuk mengetahui bagaimana perlakuan khusus terhadap narapidana risiko tinggi yang berada di dalam lingkungan LAPAS Kelas 1 Makassar serta implementasi kebijakan perlakuan khusus terhadap narapidana risiko tinggi dilembaga pemasyarakatan.

\section{METODE}

Dalam melaksanakan penelitian ini penulis telah menentukan lokasi penelitian yakni di Lapas kelas I yang berada di Kota Makassar. Pemilihan lokasi tersebut telah dipertimbangkan secara objektif demi mendapatkan bahan penelitian berupa data akurat dan lengkap sehingga diharapkan menghasilkan sebuah penelitian ilmiah yang berkualitas sangat baik.

Jenis data yang digunakan dalam penelitian ini, antara lain. Teknik Pengumpulan Data yaitu dengan Pengamatan (Observasi) Peneliti melakukan pengamatan mengenai teknis pelaksanaan pemenuhan hak-hak narapidana risiko tinggi untuk mendapatkan program pembebasan bersyarat di Lapas Kelas I Makassar. Dokumentasi Peneliti akan mengumpulkan data-data tertulis yang ada dilokasi penelitian. Wawancara Peneliti melakukan tanya jawab kepada pihak-pihak yang terkait antara lain kepada narapidana risiko tinggi dan pegawai Lapas Kelas I Makassar. Analisis data ialah suatu bentuk pola penyederhanaan sebuah data kedalam bentuk kalimat kalimat yang mudah dibaca dan diinterpretasikan. Analisis data yang dirangkum lewat penelitian dilapangan maupun penelitian kepustakaan kemudian disusun secara sistematis dan selanjutnya diwujudkan dalam bentuk penjabaran atau uraian secara terperinci.

\section{HASIL DAN PEMBAHASAN}

3.1. Assesment Resiko dan Assesment Kebutuhan yang diperlukan oleh Narapidana bisa menurunkan high risk di Lembaga Permasyarakatan

a) Petugas permasyarakatn mendata narapidana yang akan diusulkan pembebasan bersyarat

Lapas kelas I Makassar dalam melaksanakan visi Direktorat Jenderal Pemasyarakatan yakni Terwujudnya warga yang menjadi binaan pemasyarakatan agar mandiri dengan didukung oleh petugas yang memiliki kompetensi tinggi yang mampu mewujudkan tertib Pemasyarakatan. Dengan diiringi Misi

1. Menegakkan hukum serta HAM terhadap tahanan, narapidana, anak dan klien pemasyarakatanan;

2. Mengembangkan pengelolaan pemasyarakatan dan menerapkan standar pemasyarakatan berbasis IT;

3. Meningkatkan partisipasi masyarakat;

4. Mengembangkan profesionalisme dan budaya kerja yang bersih dan bermartabat;

5. Melakukan pengkajian dan pengembangan penyelenggaraan pemasyarakatan.

Lembaga Pemasyarakatan (LAPAS) dalam sistem peradilan berfungsi untuk memperbaiki terpidana (the function of correction) agar terpidana kembali menjalankan kehidupan normal dan produktif (return to a normal and productive life) ditengah -tengah masyarakat setelah menjalani masa hukumannya (Ruslan, 2014)

Adapun arah proses pembinaan serta sasaran pembimbingan WBP di Lapas Kelas I Makassar itu sendiri yaitu meningkatkan kualitas WBP yang mulanya sebahagian bahkan seluruhnya dalam kondisi kurang, seperti:

1. Kualitas Takwa Kepada Tuhan Yang Maha Esa.

2. Kualitas Intelektual

3. Kualitas attitude / Sikap

4. Kualitas profesional/keterampilan

5. Kualitas kesehatan meliputi jasmani serta rohani

Itu semua pada dasarnya demi terwujudnya pelaksanaan sistem Pemasyarakatan dengan menyisipkan target menurunnya angka pelarian dan gangguan keamanan dan ketertiban. Meningkatnya secara periode kuantitas / jumlah narapidana yang lepas sebelum waktunya mengikuti proses assimilasi dan integrasi, semakin menurunnya angka residivis, akan mewujudkan lingkup pembinaan yang berorientasi pada bertumbuhnya penilaian positif masyarakat kedalam Lembaga pemasyarakatan dan semakin meminimalisir sub-kultur penjara, sehingga akan menghindari yang namanya over kapasitas. Adapun pembagian ruangan yang terdapat didalam Lapas Kelas I Makassar antara lain :

1. Ruang Kepala Lapas Kelas I Makassar

2. Ruang kantor bersantai

3. Ruang aula serbaguna

4. Ruang kunjungan, pembinaan, dan keamanan

5. Blok penghuni terdiri dari 9 blok (daya tampung 740 orang)

6. Tempat ibadah (Masjid dan Gereja)

7. Ruang Poliklinik

8. Rumah sakit

9. Ruang keterampilan kerja

10. Pos jaga atas 6 unit

11. Ruang dapur dan gudang

12. Lapangan dan sarana olahraga

13. Rumah dinas pegawai 
Petugas melakukan Penelitian Kemasyarakatan (Litmas) sebagai risk assessment dengan peran penting dalam menentukan program pembinaan yang tepat bagi narapidana. Dengan diketahui kebutuhan kriminogeniknya maka Lapas/Rutan dapat memberikan intervensi/perlakuan yang tepat sesuai dengan tingkat risikonya untuk mengurangi risiko terjadinya pengulangan pidana. Pembebasan bersyarat sebagai salah satu proses pembinaan oleh narapidana yang telah melalui dua pertiga masa pidananya. Mekanisme pengusulan Pembebasan Bersyarat adalah harus adanya Penelitian Kemasyarakatan yang disusun oleh Pembimbing Kemasyarakatan pada Balai Pemasyarakatan. Dengan mengetahui kebutuhan kriminogenik narapidana, seorang narapidana mendapatkan penilaian kelayakan untuk melanjutkan pembimbingan diluar lembaga pemasyarakatan. Bagi narapidana yang nantinya memperoleh pembebasan bersyarat maka akan diketahui program lanjutan yang diterima setelah berbaur bersama masyarakat. Namun pada prakteknya Litmas belum mampu menggali kebutuhan kriminogenik dalam rangka menentukan program pembinaan lanjutan yang tepat bagi narapidana yang akan menjalankan pembebasan bersyarat. Laporan Penelitian Kemasyarakatan baru sekedar menjadi syarat kelengkapan untuk program pembebasan bersyarat. Penelitian Kemasyarakatan belum dapat menyajikan data yang valid untuk memprediksi risiko pengulangan kejahatan dan menggali kebutuhan kriminogenik masing-masing narapidana dalam rangka menentukan program perlakuan yang tepat.

Pemasyarakatan merupakan komponen terakhir dalam sistem peradilan pidana maupun dalam proses peradilan pidana. Sebagai sebuah tahapan pemidanaan terakhir, sudah semestinya dapat memenuhi harapan dan tujuan dari sistem peradilan pidana terpadu yang ditopang oleh pilar-pilar proses pemidanaan dari mulai kepolisian, kejaksaan, dan pengadilan. Harapan dan tujuan tersebut dapat berupa aspek pembinaan terhadap penghuni Lembaga Pemasyarakatan (Tolib,2013)

Berdasarkan hasil wawancara peneliti dengan Kepala Lapas Kelas I Makassar Bapak Budi Sarwono, mengatakan bahwa dari Litmas yang dilakukan identifikasi tidak menemukan perbedaan dalam pengungkapan informasi yang spesifik berdasarkan jenis kejahatan. Pembimbing Kemasyarakatan belum mengklasifikasikan penggunaan Litmas sebagai risk assessment berdasarkan jenis kejahatannya.

Dengan keadaan seperti ini tentunya harus segera dilakukan pembenahan di semua lini, baik Bapas, Lapas maupun Rutan. Risk assessment sebagaimana digunakan dibeberapa Negara merupakan suatu komponen yang penting untuk menentukan keberhasilan perlakuan terhadap narapidana. Penilaian risiko yang mulai dikenal dan dikembangkan di Indonesia pada saatnya nanti akan dirasakan berguna untuk menentukan keberhasilan pembinaan terhadap narapidana.

Kasi Pembimbing Kemasyarakatan Bapak Rusdi, mengatakan bahwa Lapas mempunyai peranan penting sejak awal masuk hingga proses keluarnya narapidana. Artinya pelaksanaan assessment narapidana wajib untuk dilakukan meskipun belum adanya berkas permintaan oleh pihak Lembaga pemasyarakatan maupun Rutan. Hal ini sebagai persiapan dalam mengambil keputusan apakah narapidana yang bersangkutan masuk kedalam klasifikasi kategori di
Lembaga pemasyarakatan level Maksimum, atau Minimum maupun Medium.

Tabel 1

Data Hunian Lapas Makassar Tahun 2015 s/d 2019 (Kapasitas Max 740 orang)

\begin{tabular}{|c|c|c|c|c|c|c|c|c|c|c|c|c|c|}
\hline \multirow{2}{*}{ No } & \multirow{2}{*}{ Status } & \multicolumn{6}{|c|}{ Semester I } & \multicolumn{6}{|c|}{ Semester II } \\
\hline & & Jan & Feb I & Mar & Apr & Mei . & Jun & Jul & Ags & Sep & Okt & Nov & Des \\
\hline 1 & Tahanan & 197 & 208 & 207 & 190 & 188 & 183 & 180 & 191 & 185 & 180 & 192 & $\overline{199}$ \\
\hline 2 & Narapidana & 582 & 573 & 592 & 624 & 612 & 616 & 593 & 573 & 609 & 566 & 576 & 577 \\
\hline 3 & Sandra & 0 & 0 & 0 & 0 & 0 & 0 & 0 & 0 & 0 & 0 & 0 & 0 \\
\hline & & 77 & 81 & 90 & 14 & 0 & 00 & 799 & 773 & 64 & 794 & 746 & $\overline{768}$ \\
\hline
\end{tabular}

Sumber: Lapas Kelas I Makassar, 2019

Dari data diatas menunjukkan bahwa rata-rata hunian di Lapas Makassar cenderung naik turun, baik yang berstatus Narapidana maupun Tahanan. Keadaan ini dipengaruhi oleh adanya beberapa remisi, remisi manula, remisi sakit, remisi anak, remisi khusus, remisi umum dan remisi dasawarsa.

Tabel 2

Data Penghuni Berdasarkan Kasus

\begin{tabular}{clcc}
\hline No & Perkara & Semester I & Semester II \\
\hline 1 & Pembunuhan & 278 & 279 \\
2 & Penganiayaan & 58 & 47 \\
3 & KDRT & 5 & 7 \\
4 & Pencurian & 110 & 112 \\
5 & Pelecehan & 167 & 156 \\
6 & Narkoba & 13 & 18 \\
7 & Korupsi & 144 & 143 \\
8 & Penipuan & 5 & 7 \\
9 & Teoris & 0 & 3 \\
10 & Lain-lain & 22 & 4 \\
\hline & Jumlah & 799 & 776 \\
\hline
\end{tabular}

Sumber: Lapas Kelas I Makassar Kelas I, 2019

Dari data diatas menunjukkan penurunan dan peningkatan pada kasus-kasus tertentu tetapi masih dalam angka wajar, pada kasus yang dikategorikan lain-lain membawa sajam / anak panah ada penurunan yang signifikan karena adanya diversi bagi anak bermasalah dengan hukum.

b) Usulan program risiko tinggi wajib melengkapi dokumen syarat dan ketentuan.

Dalam pemberian pembebasan bersyarat permasalahan yang penulis bahas adalah mengenai bagaimanakah pelaksanaan Pembebasan Bersyarat di Lapas Kelas I Makassar sebagaimana yang dirumuskan dalam Passal 15 KUHP sampai Pasal 16 KUHP. Dari uraian Pasal 15 ayat 1, ayat 2 dan ayat 3 Kitab Undang-undang Hukum Pidana dapat disimpulkan bahwa pembebasan bersyarat adalah hak bagi narapidana yang telah menjalani dua per tiga (2/3) periode hukuman, akan tetapi hal ini tidak begitu saja bagi narapidana untuk memperoleh pembebasan bersyarat, mereka harus memenuhi syarat-syarat yang telah ditentukan berdasarkan ketentuan yang ada.

Berdasarkan hasil wawancara penulis dengan Kepala Bidang Pembinaan Napi Bapak Sony Sopyan pada tanggal 20 Desember 2019, mengatakan bahwa Pemberian Pembebasan Bersyarat memiliki maksud dan tujuan, yaitu agar nantinya para narapidana memperoleh kesempatan untuk beradaptasi dan berbaur kembali dengan masyarakat luas agar menjelang kebebasannya nantinya eks-narapidana tidak tersisikan dan terkucilkan dalam masyarakat.

Adapun syarat-syarat sebagaimana yang telah ditentukan dalam Keputusan Menteri Kehakiman RI Nomor. M.01.04.10 Tahun 1999 tentang Asimilasi, Cuti menjelang bebas dan Pembebasan Bersyarat. 
(1) Syarat Substantif

- Telah memperlihatkan kesadaran dan menumbuhkan rasa menyesal atas perbuatan salah yang diperbuat dan berimbas pada proses pemberian hukuman pidana;

- Telah memperlihatkan perkembangan moral, nilainilai integritas yang positif;

- Mampu untuk mengikuti program agenda pembinaan dengan rajin diikuti secara berkala dan menjaga semangat;

- Masyarakat telah dapat menerima program pengajuan pembebasan bersyarat yang bersangkutan;

- Selama menjalani proses hukum pidana, narapidana atau anak pidana tidak boleh mendapat sanksi hukuman disiplin sekurang-kurangnya kurun waktu sembilan bulan terakhir;

- Periode pidana yang telah dijalani; napi telah melalui Duapertiga (2/3) dari masa pidananya, setelah dikurangi masa tahanan dan remisi dihitung mulai tanggal putusan pengadilan yang memperoleh kekuatan hukum tetap dengan ketentuan dua pertiga (2/3) tersebut tidak kurang dari Sembilan (9) bulan,

Syarat substantif ini dilakukan oleh narapidan yang akan mengajukan pengusulan pembebasan bersayarat. Persyaratan tersebut akan mempengaruhi persetujuan narapidana untuk bebas

(2) Syarat Administratif

- Salinan surat keputusan pengadilan;

- Surat asli yang memuat keterangan oleh kejaksaan bahwa narapidana tersebut sudah tidak lagi mempunyai perkara atau yang menyangkut tindak pidana lainnya;

- Surat Laporan penelitian kemasyarakatan (Litmas) oleh bapas menyangkut pihak kerabat / keluarga yang ingin menerima status narapidana, diterima oleh keadaan lingkungan sosial masyarakat sekitarnya serta pihak luar yang erat kaitannyanya dengan narapidana;

- Salinany / daftar huruf F adalah dokumen yang berisikan tentang pelanggaran kepatuhan dan tata tertib yang dilakukan oleh narapidana, selama menjalankan masa pidana dari kepala lembaga pemasyarakatan;

- Salinan dokumen data pengurangan atau perubahan masa pidana, seperti remisi, grasi dan jenis lainnya dari kepala lembaga pemasyarakatan;

- Dokumen berupa pernyataan bersedia untuk menyanggupi narapidana agar dapat diterima, seperti pihak lingkup keluarga, pendidikan / sekolah, kantor pemerintah maupun swasta kemudian ditembuskan untuk diketahui pemerintah setempat (kepala desa atau lurah) Surat keterangan berbadan sehat / surat pernyataan dari psikolog maupun dari dokter bahwa kondisi narapidana dalam keadaan sehat jasmani dan jiwa , apabila pada kantor Lapas tidak ada dokter atau psikiater, maka dengan demikian surat pernyataan keterangan tersebut dapat dibuatkan pada rumah sakit umum atau dokter puskesmas;

- Bagi napi atau anak pidana Warga Negara Asing membutuhkan syarat tambahan yaitu Surat pernyataan keterangan kesanggupan memberi jaminan yang dikeluarkan oleh kedutaan besar (konsulat Negara) orang asing yang bersangkutan dan
Surat rujukan atau rekomendasi yang dikeluarkan oleh kantor imigrasi sesuai wilayah.

Tabel 3

Data Usulan dan Realisasi Program CB, CMB dan PB

\begin{tabular}{cccccc}
\hline \multirow{2}{*}{ No } & \multirow{2}{*}{ Program } & \multicolumn{2}{c}{ Semester I } & \multicolumn{2}{c}{ Semester II } \\
\cline { 3 - 6 } & & \multicolumn{2}{c}{ Usulan Realisasi Usulan Realisasi } \\
\hline 1 & Pembebasan Bersyarat & 113 & 104 & 119 & 122 \\
2 & Cuti Menjelang Bebas & 3 & 1 & 9 & 8 \\
3 & Suti Bersyarat & 17 & 13 & 11 & 17 \\
\hline & Jumlah & 123 & 118 & 139 & 137 \\
\hline
\end{tabular}

Sumber: Lapas Kelas I Makassar, 2019

Data diatas menunjukan bahwa usulan Pembebasan Bersyarat, Cuti Bersyarat dan Cuti Menjelang Bebas mengalami peningkatan, terutama usulan Pembebasan Bersyarat naik 27\%. Keadaan ini jauh lebih baik karena selain meningkat juga lebih tepat waktu. Sebaliknya untuk realisasi sangat mengecewakan yaitu menurun $11 \%$, keadaan ini sangat meresahkan WBP karena yang seharusnya sudah dapat melaksanakan tetapi terhambat.

Tabel 4

Daya Upaya Penanggulangan Over Kapasitas

\begin{tabular}{|c|c|c|c|}
\hline No & Program & Semester I & Semester II \\
\hline 1 & Pemindahan ke UPT lain & 6 & 14 \\
\hline 2 & $\begin{array}{l}\text { Pembebasan karena PB, CB, } \\
\text { CMB }\end{array}$ & 118 & 137 \\
\hline 3 & Pembebasan karena Remisi & 51 & 74 \\
\hline 4 & $\begin{array}{l}\text { Pembebasan karena Habis } \\
\text { Masa Pidana }\end{array}$ & 72 & 83 \\
\hline 5 & Penangguhan dan Diversi & 19 & 27 \\
\hline 6 & Pembebasan Demi Hukum & 1 & 2 \\
\hline & Jumlah & 267 & 337 \\
\hline
\end{tabular}

Sumber: Lapas Kelas I Makassar, 2019

Data di atas menggambarkan bahwa upaya penanggulangan over kapasitas dengan memindahkan ke UPT terdekat kurang karena Lapas Kelas I Makassar sebagai UPT penerima dari UPT lain juga over kapasitas atau dengan alasan keamanan, selain itu pembebasan dengan pembinaan baik Pembebasan Bersyarat, Cuti Bersyarat dan Cuti Menjelang Bebas mengalami peningkatan dari tahun ke tahun.

3.2. Hambatan - hambatan di dalam pelaksanaan pemberian pembebasan bersyarat bagi narapidana tingkat risiko tinggi di Lapas Kelas I Makassar

a) Tidak adanya jaminan yang kuat dari penerima program pembebasan bersayarat untuk tidak mengulangi tindak pidana

Selain diri sendiri narapidana, dalam pembinaan, modal dasar selanjutnya yang harus terpenuhi dalam mengambil bagian secara aktif pada proses pembinaan narapidana adalah dating dari keluarga dekat yang peduli. Keluarga wajib berperan aktif dalam membina keluarga yang telah melekat status narapidana, sebah hanya keluarga orang paling dekat dan memiliki pengaruh besar dalam membentuk perilaku narapidana.

Berdasarkan hasil wawancara penulis dengan Kepala Bidang Pembinaan Napi Bapak Sony Sopyan mengatakan bahwa, hanya keluarga yang harmonis saja yang berperan positif dalam pembinaan narapidana. Selebihnya jika narapidana datang dari rumpun keluarga yang harmonis, peran membina narapidana yang masih anggota keluarganya yang kurang berhasil mendapat perhatian. Tentu agak sulit untuk mendapatkan masukan, apakah hubungan antara narapidana dengan keluarganya harmonis atau tidak. Tetapi bagaimana 
sulitnya, maka sulit bukan berarti tidak bisa. Adalah tugas Lembaga Pemasyarakatan/Rutan untuk mengumpulkan keluarga narapidana dan memberi masukan tentang pentingnya pembinaan narapidana oleh keluarga. Sebab itu keluarga harus mengetahui proses, materi, perkembangan pembinaan yang akan dilakukan oleh pihak Lembaga Pemasyarakatan/Rutan. Jika keluarga sama sekali tidak mengertahui proses, materi, perkembangan pembinaan narapidana, maka kita tidak boleh berharap banyak peran keluarga dalam membina anggota keluarganya yang menjadi narapidana.

Pembinaan narapidana lahir dari proses pemidanaan. Tujuan pembinaan narapidana lahir karena proses pemidanaan. Jika kita telusuri lebih dalam, maka tugas keluarga diharapkan memiliki tanggung jawab dalam membina narapidana. Dalam pembinaan narapidana, keluarga diharapkan tetap berperan secara aktif untuk membina, membimbing secara berkala anggota keluarga yang menjadi narapidana. Langkah dan upaya tersebut berdasar atas berbagai pertimbangan, yaitu:

1. Narapidana adalah bagian dari keluarga.

2. Diharapkan terjalin kerjasama antara keluarga dan Lembaga Pemasyarakatan/Rutan dalam membina narapidana.

3. Perlu sumbang saran, komunikasi timbal balik dari keluarga dan pihak Lembaga Pemasyarakatan/Rutan dalam membina narapidana.

4. Perlu pembinaan terus menerus oleh pihak keluarga terhadap anggota keluarga yang menjadi narapidana.

b) Masih Menjadi Kontroversi Dan Sorotan Kritis Dari Masyarakat

Upaya untuk mengatasi hambatan - hambatan dalam pelaksanaan pembebasan bersyarat di Lapas Kelas I Makassar, bagi lingkungan masyarakat maupun lingkup keluarga yang tidak ingin menerima mantan narapidana disebabkan adanya rasa malu dan potensi mencemarkan nama baik. Dalam hal mengatasi masyarakat maupun dari keluarga yang tidak ingin menerima narapidana seharusnya diberi pemahaman tentang hak progratif dari keluarga maupun masyarakat agar ingin menerima dan ikut memberikan bimbingan bagi narapidana yang telah diberikan pembebasan bersyarat agar setiap narapidana memang benar - benar dianggap masih berguna dan bermanfaat bagi keluarga dan masyarakat supaya menjadi sosok manusia seutuhnya yang berubah menjadi manusia yang baik, sadarakan perbuatan kesalahan yang pernah dilakukan, berbenah diri serta berjanji atas diri sendiri untuk tidak mengulang perbuatan perilaku pidana sehingga masyarakat dapat menerima kembali dilingkungannya dan ikut berperan aktif dalam pembangunan berbagai kegiatan social untuk mewujudkan kembali status sebagai warga masyarakat yang bertanggung jawab dan baik.

Berdasarkan hasil wawancara dengan Kasi Pembimbing Kemasyarakatan Bapak Rusdi pada tanggal 20 Desember 2019, mengatakan bahwa hambatan - hambatan dalam pelaksanaan pembebasan bersyarat di Lapas Kelas I Makassar dibedakan menjadi faktor internal maupun faktor external.

Faktor eksternal yang meliputi:

1. Pihak dari keluarga serta masyarakat pada umumnya masih belum mau menerima status mantan narapidana disebabkan adanya rasa malu dan takut merasa nama baik akan tercemar,
2. Izin Domisili yang tidak serta merta diberikan oleh kepala lingkungan / RT atau Kepala Desa / Lurah tergantung tempat dimana narapidana pernah tinggal,

3. Pihak BAPAS terlambat membuat Litmas maka akan menghambat proses pembuatan atau penerbitan SK Pembebasan Bersyarat,

4. Tahapan dalam proses Pembebasan Bersyarat pada kenyataannya membutuhkan waktu yang cukup Iama.

Sementara itu faktor internal yang terdiri: Narapidana pada saat menunggu proses Pembebasan Bersyarat terkadang melanggar aturan disiplin di dalam Rutan dan Syarat Substantif dan Syarat Administratif tidak terpenuhi secara penuh.

Kesulitan yang pada umumnya dialami oleh narapidana yaitu butuh proses lama untuk mendapatkan kembali simpatik, rasa kepercayaan oleh masyarakat sekitarnya, dan kesulitan lainnya berdampak pada tidak mudahnya untuk dapat pekerjaan. Hal ini bagi mantan narapidana, untuk kembali lagi hadir ketengah-tengah masyarakat, ada rasa takut akan dikucilkan, terpinggirkan bahkan dihina oleh masyarakat. Karena merasa terpinggirkan rendah diri, dan sudah tidak memiliki rasa percaya diri yang tinggi bahwa dia juga manusia yang memiliki hak untuk bersosialisasi berperan aktif lingkungannya.

Sahardjo menyatakan bahwa keikut sertaan masyarakat baik itu kerjasama dalam pembinaan ataupun dengan sikap bersedia menerima kembali Warga Binaan Pemasyarakatan (selanjutnya disingkat WBP) yang telah selesai menjalani pidananya adalah hal yang diperlukan untuk mewujudkan sistem pemasyarakatan yang baik (Dwidja Priyatno, 2006).

Dalam Sistem Program Pemasyarakatan Indonesia yang mengadopsi tipe penghukuman reintegrasi sosial dan rehabilitasi, narapidana yang telah menjalani hukuman harus dibuat jera dan tetap diberi pembinaan agar bisa menjadi bagian masyarakat yang baik. Pada proses program pembinaan di Lapas/Rutan, semua narapidana harus menjalani tiga bagian, yaitu yang menjadi tahap awal minimum security, medium security, maximum security. Setelah narapidana telah menjalani tiga rangkaian tahapan ini, maka narapidana layak dan berhak untuk mendapatkan program pembebasan bersyarat atau pemulihan kembali atas status sosial. Disposisi pemulihan kembali status sosial terhadap narapidana di Indonesia diantaranya Cuti Bersyarat, Cuti Kunjungan Keluarga, Cuti Menjelang Bebas, serta Pembebasan Bersyarat.

Narapidana layak dan berhak untuk mendapatkan program pembebasan bersyarat jika telah menjalani dua per tiga masa hukuman. Pembebasan bersyarat ini juga merupakan bagian dari proses reintegrasi sosial untuk narapidana terhadap lingkungan masyarakat, yang dimana kelak narapidana tersebut berdomisili. Mantan narapidana jika hidup berbaur bersama dengan masyarakat. mereka tidak adalagi merasa canggung, merasa diawasi oleh pegawai Lapas/Rutan tetapi hal ini membuat dirinya merasa diawasi dan diamati langsung dengan masyarakat dan secara periode masyarakat dan mantan narapidana tersebut tetap dibimbing oleh pembimbing dari Bapas.

\section{KESIMPULAN DAN SARAN}

Berdasarkan hasil penelitian dapat disimpulkan bahwa optimalisasi dari Litmas Pemindahan ditentukan oleh sinergitas Wali Pemasyarakatan dan Pembimbing 
Kemasyarakatan karena dalam Revitalisasi

Penyelenggaraan Pemasyarakatan, Wali berperan untuk mencatat sikap dan perilaku Narapidana dalam sebuah laporan harian. Sehingga pengawasan yang dilakukan oleh PK secara berkala melalui tatap muka dengan klien serta koordinasi dengan wali untuk melihat tingkat perkembangan narapidana maka potensi perubahan tingkat klasifikasi dapat terwujud melalui sarana Litmas Pemindahan yang di dalamnya terdapat instrument assesmen risiko, assesmen kebutuhan dan assesmen 5 dimensi. Hal inilah yang menunjukkan korelasi assesmen risiko dan assesmen kebutuhan terhadap penurunan tingkat high risk.Lapas mempunyai peranan penting sejak awal masuk hingga proses keluarnya narapidana. Artinya pelaksanaan assessment narapidana wajib hukumnya dilakukan walaupun tanpa adanya surat permintaan dari pihak Lapas maupun Rutan. Hal ini sebagai bahan pengambilan keputusan apakah napi tersebut masuk dalam kategori di Lapas Maksimum Security, Medium Security atau Minimum Security

\section{DAFTAR PUSTAKA}

Effendi, Tolib. 2013. Sistem Peradilan Pidana. Yogyakarta: Pustaka Yustisia

Peraturan Menteri Hukum \& Hak Asasi Manusia No. 35 Th. 2018 tentang Revitalisasi Penyelenggaraan Pemasyarakatan.

Priyatno, Dwidja. 2006. Sistem Pelaksanaan Pidana Penjara di Indonesia. Bandung: PT. Refika Aditama

Renggong, Ruslan. 2014. Hukum Acara Pidana - Memahami Perlindungan HAM dalam Proses Penahanan di Indonesia. Jakarta. Kencana

Rusdi. (2020 Desember 20). Hambatan Di dalam Pelaksanaan Bebas Bersyarat (Rosliani ,Pewawancara)

Sarwono,Budi (2020 Desember 20) Petugas Kemasyarakatan mendata Narapidana Yang diusulkan pembebasan bersyarat di Lapas Kelas 1 Makassar(Rosliani, Pewawancara)

Sopyan, Soni (2020 Desember 20) Pemberian Bebas Bersyarat Bagi Narapidana (Rosliani, Pewawancara)

Suwarto. (2009). Pengembangan Ide Individualisasi Pemidanaan dalam Pembinaan Narapidana Wanita, Pidato pengukuhan guru besar tetap FH USU Medan. Jakarta: Raja Grafindo Persada

Undang -Undang Dasar Negara Republik Indonesia 1945 Setelah Amandemen

Lamintang dan Theo Lamintang, Hukum Penitensier Indonesia; Edisi Kedua, Sinar Grafika, Jakarta, 2010.

Dwidja Priyatno. 2006. Pidana Penjara di Indonesia. Bandung: Rafika Aditama.

Surat Instruksi Kepala Direktorat Pemasyarakatan Nomor J.H.G.8/506 tanggal 17 Juni 1964

Keputusan Menteri Kehakiman RI Nomor. M.01.04.10 Tahun 1999 tentang Asimilasi, Cuti menjelang bebas dan Pembebasan Bersyarat.

Peraturan Dirjen Pemasyarakatan Nomor PAS-58.OT.03.01 Tahun 2010 tentang Prosedur Tetap Perlakuan Narapidana Risiko Tinggi (Protap Pelakuan Narapidana Risiko Tinggi)

Immawati, A., Renggong, R., \& Siku, A. S. (2021). Efektivitas Pengawasan Terhadap Narapidana Yang Mendapatkan Pembebasan Bersyarat Dari Balai Pemasyarakatan Kelas I Makassar. Indonesian Journal of
Legality

of

Law, 2(2),

https://doi.org/10.35965/ijlf.v2i2.455 